\title{
Escin Ia suppresses the metastasis of triple-negative breast cancer by inhibiting epithelial-mesenchymal transition via down-regulating LOXL2 expression
}

\author{
Yuhui Wang ${ }^{1, *}$, Xiaotian Xu ${ }^{1, *}$, Peng Zhao ${ }^{1}$, Bei Tong ${ }^{1}$, Zhifeng Wei ${ }^{1}$, Yue Dai ${ }^{1}$ \\ ${ }^{1}$ Jiangsu Key Laboratory of Drug Discovery for Metabolic Diseases, Department of Pharmacology of Chinese Materia Medica, \\ China Pharmaceutical University, Nanjing 210009, China \\ *These authors are contributed equally to this work \\ Correspondence to: Yue Dai, e-mail: yuedaicpu@hotmail.com \\ Zhifeng Wei, e-mail: zhifeng-wei@hotmail.com
}

Keywords: escin Ia, triple-negative breast cancer, metastasis, epithelial-mesenchymal transition, lysyl oxidase-like 2

Received: December 19, 2015

Accepted: March 02, 2016

Published: March 17, 2016

\section{ABSTRACT}

The saponin fraction of Aesculus chinensis Bunge fruits (SFAC) could inhibit the invasion and migration of MDA-MB-231 cells. Among which, escin Ia showed more potent inhibition of the invasion than other five main saponin constituents. It selectively reduced the expression of LOXL2 MRNA and promoted the expression of E-cadherin mRNA, and prevented the EMT process of MDA-MB-231 cells and TNF-a/ TGF- $\beta$-stimulated MCF-7 cells. Moreover, it reduced the LOXL2 level in MDA-MB-231 cells but not in MCF-7 cells. When MCF-7 cells were stimulated with TNF-a/TGF- $\beta$, transfected with LOXL2 or treated with hypoxia, escin Ia down-regulated the level of LOXL2 in MCF-7 cells. Meanwhile, escin Ia suppressed the EMT process in LOXL2transfected or hypoxia-treated MCF-7 cells. Of interest, escin Ia did not alter the level of HIF-1a in hypoxia-induced MCF-7 cells. In TNBC xenograft mice, the metastasis and EMT of MDA-MB-231 cells were suppressed by escin Ia. In conclusion, escin Ia was the main active ingredient of SFAC for the anti-TNBC metastasis activity, and its action mechanisms involved inhibition of EMT process by down-regulating LOXL2 expression.

\section{INTRODUCTION}

Triple-negative breast cancer (TNBC) is an aggressive subtype of breast cancers, which shows higher metastases and relapse rates than other types. Usually, TNBC is treated with chemotherapeutic agents (e.g., doxorubicin, paclitaxel and cisplatin), but its relapse rate is high in the first three years due to the development of drug resistance. In addition, neither tamoxifen nor trastuzumab which can effectively treat other subtypes of breast cancers is effective for TNBC due to the lack of estrogen receptors (ER), progesterone receptors (PR) and human epidermal growth factor receptor 2 (HER2) $[1,2]$. Therefore, the conventional chemotherapy and the current targeted therapy are unsatisfactory for the treatment of TNBC, and it is urgent to explore new therapeutic measures with lower toxicity and high efficiency.

Metastasis is a quite complicated process, in which the cancer cells break away from primary tumors, invade surrounding tissues, and migrate into other organs (e.g., bone, lung and brain) of the body through blood vessels and lymphatic vessels. Data have indicated that most of patients with TNBC had lymph node metastasis, and died of the complications caused by it. Currently, various promising researches are underway for the identification of new biologics and targeted agents for TNBC treatment, such as those about epidermal growth factor receptor (EGFR) inhibitors, vascular endothelial growth factor (VEGF) inhibitors and lysyl oxidase-like 2 (LOXL2) inhibitors. Prevention of metastasis might be an effective approach for the successful treatment of TNBC [3].

Aesculus chinensis Bunge is a deciduous tree that widely distributes in China, and its fruits have long been used for the treatment of various diseases. Evidence indicated that the saponin fraction from $A$. chinensis fruits (SFAC) possesses anti-edematous and anti-inflammatory activities [4, 5]. Also, SFAC exerted anti-cancer activity as shown by inhibition of proliferation and induction of apoptosis in HL-60 cells [6]. Our previous study demonstrated that SFAC could inhibit the invasion 
(an initiative process of metastasis) of MDA-MB-231 cells (one type of highly aggressive mammary cancer cell) but not their proliferation, apoptosis and angiogenesis (Figure $\mathrm{S} 1$ and S2). In the present study, we investigated the main anti-invasion constituent of SFAC, and characterized its action mechanisms for inhibition of TNBC metastasis.

\section{RESULTS}

\section{Identification of the main anti-invasion constituent of SFAC}

Our previous studies demonstrated that SFAC $(5,10,20 \mu \mathrm{g} / \mathrm{mL})$ could inhibit the invasion of MDAMB-231 cells but not their proliferation, apoptosis and angiogenesis of HUVECs. In order to recognize the major anti-invasion constituent of SFAC, six saponin constituents (escin Ia, escin Ib, escin IIa, escin IIb, escin $\mathrm{IIIa}$ and escin $\mathrm{IIIb}$ ) isolated from it were screened by cell invasion assay (Figure 1A-1F). As shown in Figure 2A, significant invasion of MDA-MB-231 cells was observed in normal group, and escin Ia $(5 \mu \mathrm{M})$ showed stronger inhibition (inhibition ratio: $68.92 \%$ ) than escin $\mathrm{Ib}$ (inhibition ratio: $63.93 \%$ ), escin IIa (inhibition ratio: $34.02 \%$ ), escin IIb (inhibition ratio: $33.14 \%$ ), escin IIIa (inhibition ratio: $48.39 \%$ ) and escin IIIb (inhibition ratio: 55.72\%). In addition, escin Ia $(2.5,5,10 \mu \mathrm{M})$ inhibited the invasion of MDA-MB-231 cells by $39.46 \%, 64.22 \%$ and $76.23 \%$, respectively (Figure $2 \mathrm{~B}$ ). The findings in association with the fact that the content of escin Ia in $A$. chinensis is much higher than escin Ib suggested that escin Ia was the major anti-invasion active constituent of SFAC [7].

\section{Escin Ia inhibited invasion process of MDA- MB-231 cells by down-regulating the expression of LOXL2 and up-regulating the expression of E-cadherin}

The invasion of tumor cells could be regulated by many factors such as BRMS1, E-cadherin, Keratin19, LOXL2, MMP9, Orai1, Stim1, TGF- $\beta$ and VEGF [8-15]. To identify the mechanisms underlying antiinvasion effect of escin Ia, its effect on the expressions of the factors mentioned above were studied. As shown in Figure 3, escin Ia $(2.5,5,10 \mu \mathrm{M})$ obviously downregulated the LOXL2 mRNA expression and up-regulated the E-cadherin mRNA expression of MDA-MB-231 cells. In addition, MMP9 mRNA expression in MDA-MB-231 cells was moderately down-regulated by escin Ia $(10 \mu \mathrm{M})$ treatment. In contrast, escin Ia only showed slight effect on the expressions of BRMS1, Keratin19, Orai1, Stim1, TGF- $\beta$ and VEGF mRNAs in MDA-MB-231 cells. These results suggested that LOXL2 and E-cadherin might play vital roles in the escin Ia-mediated inhibition of MDAMB-231 cells invasion.

\section{Escin Ia suppressed epithelial-mesenchymal transition (EMT) in MDA-MB-231 cells and TNF- $\alpha$ /TGF- $\beta$-stimulated MCF-7 cells}

LOXL2 and E-cadherin are thought to have close relevance to EMT process which could promote invasion and migration of TNBC cells. In addition, escin Ia treatment obviously elevated the mRNA expression of E-cadherin, a well-known marker of the EMT. As shown in Figure 4A, escin Ia obviously inhibited the migration of MDA-MB-231 cells. Furthermore, escin Ia elevated the protein expression of E-cadherin and reduced the protein expressions of vimentin and $\alpha$-SMA, other two markers of EMT, in MDA-MB-231 cells (Figure 4B and 4C). Of note, escin Ia $(10 \mu \mathrm{M})$ increased the protein expression of E-cadherin and reduced the protein expressions of vimentin and $\alpha$-SMA in a time-dependent manner (Figure 4D). Escin Ia $(5,10 \mu \mathrm{M})$ down-regulated the mRNA expressions of transcription factors Snail, Slug, Zeb1, Zeb2 and Twist in MDA-MB-231 cells, even though the pattern and degree of these alterations was somewhat different (Figure 4E). Overall, these results strongly suggested that escin Ia could diminish EMT process in MDA-MB-231 cells.

Subsequently, we further investigated the antiEMT effect of escin Ia in TNF- $\alpha /$ TGF- $\beta$-stimulated MCF-7 cells. When stimulated with TNF- $\alpha /$ TGF- $\beta$, MCF-7 cells gradually vanished epithelial characteristics and obtained mesenchymal characteristics, and got similar highly aggressive ability as MDA-MB-231 cells [16]. As shown in Figure $5 \mathrm{~A}$, after stimulated by TNF- $\alpha / \mathrm{TGF}-\beta$, the protein levels of E-cadherin and vimentin, $\alpha$-SMA in MCF-7 cells reached valley and peak, respectively. Escin Ia $(2.5,5,10 \mu \mathrm{M})$ prevented the morphologic transition of MCF-7 cells from epithelial-like to mesenchymal-like appearance (Figure 5B). As shown in Figure 5C and 5D, TNF- $\alpha /$ TGF- $\beta$ stimulation induced obvious invasion and migration of MCF-7 cells, and escin Ia prohibited these processes. Escin Ia reversed the reduction of the protein and mRNA expression of E-cadherin, and reversed the increase of the protein expressions of vimentin and $\alpha$-SMA caused by TNF- $\alpha /$ TGF- $\beta$ stimulation (Figure $5 \mathrm{E}-5 \mathrm{G}$ ). The effect of escin Ia $(10 \mu \mathrm{M})$ gradually increased with exposure time extending (Figure $5 \mathrm{H})$. Escin Ia $(5,10 \mu \mathrm{M})$ diminished TNF- $\alpha /$ TGF- $\beta$-induced increase of the mRNA expressions of Snail, Slug, Zeb1, Zeb2 and Twist (Figure 5I). Taken together, these results indicated that escin Ia could reverse the EMT process in TNF- $\alpha / T G F-\beta-$ stimulated MCF-7 cells.

In a word, these findings suggested that EMT repression was an important mechanism for escin Iainduced inhibition of the invasion of TNBC cells. 


\section{Escin Ia suppressed EMT process via down- regulating LOXL2}

LOXL2, a member of the lysyl oxidase family, has been identified as a vital promoting factor of EMT [17], and its mRNA expression was obviously reduced by escin Ia treatment in MDA-MB-231 cells. Moreover, escin Ia could suppress EMT process in MDA-MB-231 cells and TNF- $\alpha /$ TGF- $\beta$-stimulated MCF-7 cells. Therefore, we subsequently investigated whether inhibition of EMT by escin Ia was mediated by LOXL2. Firstly, we observed whether escin Ia inhibited LOXL2 expression in breast cancer cells. As shown in Figure 6A-6C, obvious LOXL2 protein expression was observed in MDA-MB-231 cells, and escin Ia $(2.5,5,10 \mu \mathrm{M})$ decreased LOXL2 protein expression. Moreover, TNF- $\alpha /$ TGF- $\beta$ stimulation for $72 \mathrm{~h}$ resulted in a dramatically elevated protein and
mRNA expression of LOXL2 in MCF-7 cells, which were abrogated by escin Ia treatment (Figure 6D-6G). In contrast, escin Ia showed little effect on LOXL2 expression and EMT process in MCF-7 cells (Figure S3). On the other hand, MCF-7 cells showed obvious LOXL2 expression, and exhibited a highly aggressive profile similar to MDA-MB-231 cells when transfected with LOXL2 [18]. Escin Ia and BAPN (a non-selective LOXL2 inhibitor) decreased LOXL2 expression of LOXL2transfected MCF-7 cells (Figure 6H-6K). These data in association with the fact that LOXL2 expression was low in MCF-7 cells suggested that the inhibition of EMT of escin Ia in breast cancer cells correlated with the reduction of LOXL2 expression.

In order to confirm that escin Ia inhibited EMT process through down-regulating LOXL2, we observed that effect of escin Ia on EMT process of MCF-7 cells
A

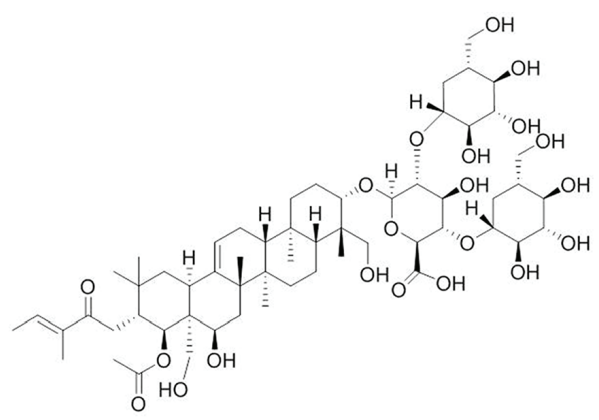

C

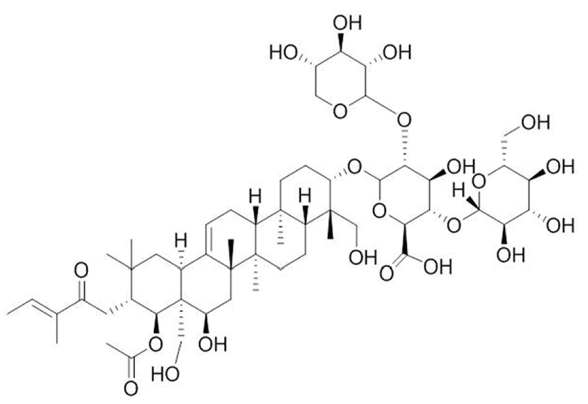

$\mathbf{E}$

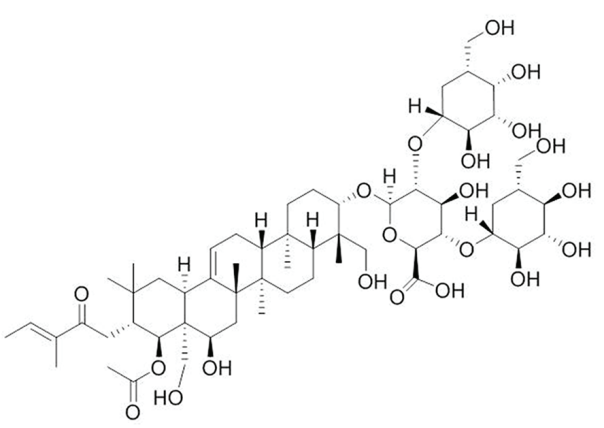

B

D

$\mathbf{F}$
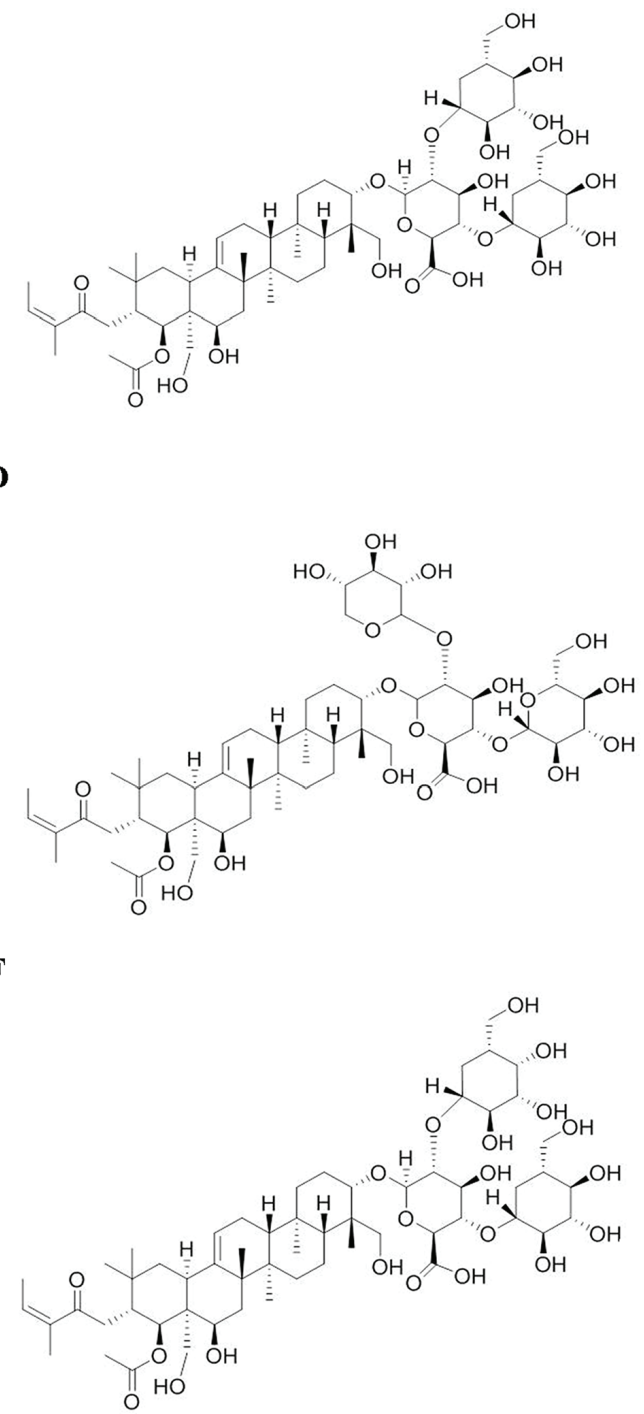

Figure 1: Chemical structures of escin Ia (A), escin Ib (B), escin IIa (C), escin IIb (D), escin IIIa (E) and escin IIIb (F). 
transfected with LOXL2. Results showed that MCF-7 cells gradually vanished epithelial characteristics and obtained mesenchymal characteristics, and exhibited a highly aggressive profile as MDA-MB-231 cells when transfected with LOXL2. As shown in Figure 7A-7C, escin Ia $(2.5,5$, $10 \mu \mathrm{M})$ and BAPN $(100 \mu \mathrm{M})$ treatments prevented the morphologic transition of LOXL2-transfected MCF-7 cells from epithelial-like to mesenchymal-like appearance, and inhibited invasion and migration of LOXL2-transfected MCF-7 cells. MCF-7 cells transfected with LOXL2 showed decreased protein and mRNA expression of E-cadherin and elevated protein expressions of vimentin, $\alpha$-SMA, and escin Ia $(2.5,5,10 \mu \mathrm{M})$ and BAPN $(100 \mu \mathrm{M})$ antagonized LOXL2-transfection-mediated downregulation of E-cadherin at protein and mRNA grades, and abrogated LOXL2-transfection-induced up-regulation of vimentin and $\alpha$-SMA at protein levels (Figure 7D-7G). In addition, escin Ia $(5,10 \mu \mathrm{M})$ and BAPN $(100 \mu \mathrm{M})$ markedly decreased LOXL2-transfection-induced increase of the mRNA expressions of Snail, Slug, Zeb1, Zeb2 and Twist (Figure 7H). These findings indicated that escin Ia inhibited EMT process mainly through down-regulating LOXL2.

Furthermore, the anti-EMT effect of escin Ia in hypoxia-stimulated MCF-7 cells was observed. Data showed that LOXL2 level in MCF-7 cells was elevated

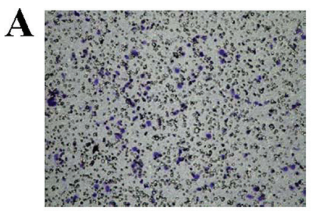

Normal

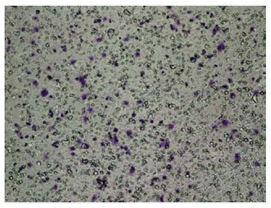

Escin IIb (5 $\mu \mathrm{M})$

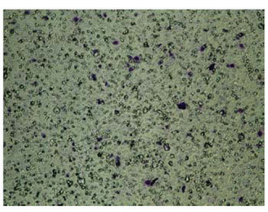

Escin Ia (5 $\mu \mathrm{M})$

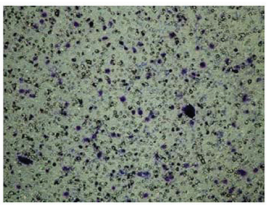

Escin IIIa (5 $\mu \mathrm{M})$

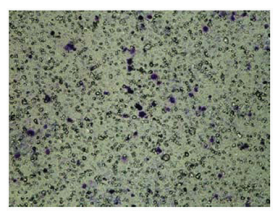

Escin Ib $(5 \mu M)$

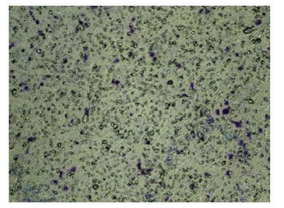

Escin IIIb (5 $\mu \mathrm{M})$

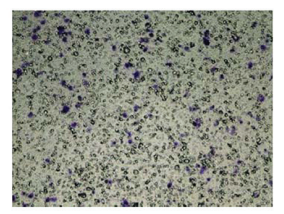

Escin IIa (5 $\mu \mathrm{M})$

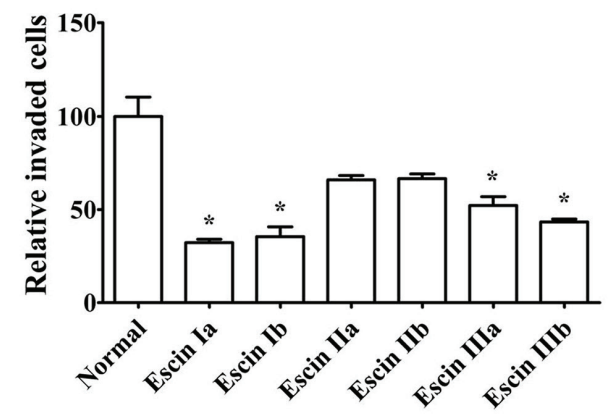

B

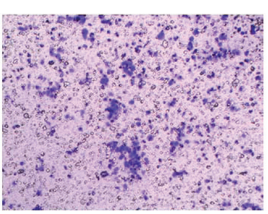

Normal

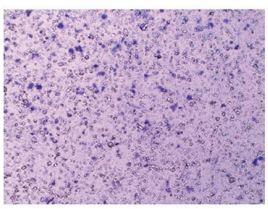

Escin Ia (5 $\mu \mathrm{M})$
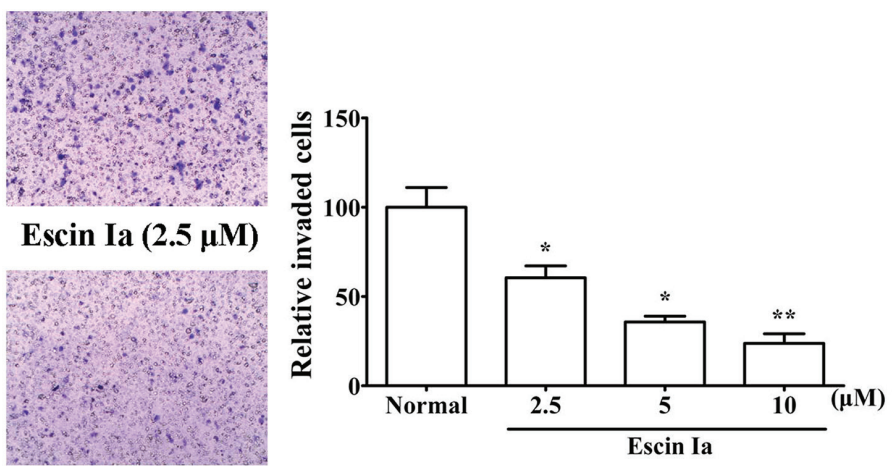

Escin Ia (10 $\mu \mathrm{M})$

Figure 2: Effect of escin Ia-IIIb on MDA-MB-231 cells invasion. (A) MDA-MB-231 cells were cultured in chambers with matrigel followed by treatment with escin Ia-IIIb $(5 \mu \mathrm{M})$ for $24 \mathrm{~h}$. The number of cells invaded through the matrigel of chambers bottom were counted in three different regions. (B) MDA-MB-231 cells were cultured in chambers with matrigel followed by treatment with escin Ia $(2.5,5,10 \mu \mathrm{M})$ for $24 \mathrm{~h}$. The number of cells invaded through the matrigel of chambers bottom were counted in three different regions. The data were expressed as the means \pm S.E.M. of three independent experiments. ${ }^{*} p<0.05, * * p<0.01 v s$. normal. 
after the cells were exposed to hypoxia. Epithelial and mesenchymal characteristics of MCF-7 cells gradually vanished and obtained, respectively. In addition, hypoxia resulted in high aggressivity of MCF-7 cells similar to MDA-MB-231 cells [19]. As shown in Figure 8A-8C, escin Ia $(2.5,5,10 \mu \mathrm{M})$ prevented the morphologic transition from epithelial-like to mesenchymal-like appearance, and prohibited the invasion and migration of hypoxia-induced MCF-7 cells. Obvious elevation of the protein and mRNA expressions of HIF-1 $\alpha$, LOXL2, vimentin, $\alpha$-SMA and decrease of protein and mRNA expression of E-cadherin were observed in hypoxiastimulated MCF-7 cells, and escin Ia $(5,10 \mu \mathrm{M})$ abrogated hypoxia-induced changes of LOXL2, vimentin, $\alpha$-SMA and E-cadherin expressions (Figure 8D-8F), but it showed little effect on the expression of HIF-1 $\alpha$ (Figure 8D). In addition, escin Ia $(5,10 \mu \mathrm{M})$ markedly decreased hypoxiainduced increase of the expressions of Snail, Slug, Zeb1, Zeb2 and Twist mRNAs (Figure 8G). These findings indicated that escin Ia inhibited EMT process through down-regulating LOXL2 expression.

\section{Escin Ia inhibited lung metastasis and EMT process in MDA-MB-231 xenograft model}

To confirm the inhibitory effect on EMT and consequent anti-metastasis activity of escin Ia, a xenograft model was established by subcutaneous injection of MDAMB-231 cells into the left and right mammary fat pads of nude mice. The metastasis from the injection sites to the lungs was studied by histological examination at seven weeks after MDA-MB-231 cells injection. The infiltration of tumor cells was observed in the lungs of mice in model group. However, no or less infiltration was detected in the lungs of escin Ia- and BAPN-treated mice. Of note, the potency of escin Ia $(4 \mathrm{mg} / \mathrm{kg})$ was superior to that of BAPN (100 mg/kg) (Figure 9A).

Tumor samples from the breasts of mice in model group, escin Ia (2 mg/kg, $4 \mathrm{mg} / \mathrm{kg})$-treated groups and BAPN (100 mg/kg)-treated groups were used to determine the effect of escin Ia on the expressions of HIF-1 $\alpha$, LOXL2 and EMT markers. It was shown that the expression of E-cadherin was lower, and the expressions of HIF-1 $\alpha$, LOXL2, vimentin, $\alpha$-SMA, Snail, Slug, Zeb1, Zeb2 and Twist were higher in the tumors in the model group. Escin Ia $(4 \mathrm{mg} / \mathrm{kg})$ and BAPN $(100 \mathrm{mg} / \mathrm{kg})$ treatments caused down-regulations of LOXL2, vimentin, $\alpha$-SMA, Snail, Slug, Zeb1, Zeb2 and Twist and up-regulation of E-cadherin at protein and mRNA grades in MDA-MB-231 xenografts mice (Figure 9B-9D). However, escin Ia $(2 \mathrm{mg} / \mathrm{kg}, 4 \mathrm{mg} / \mathrm{kg}$ ) showed little effect on protein and mRNA expression of HIF-1 $\alpha$ in breast tumors of mice (Figure 9B and 9C). Taken together, the findings indicted that escin Ia suppressed the TNBC metastasis by inhibition of EMT process and consequent invasive growth through down-regulating LOXL2.

\section{DISCUSSION}

The two primary hallmarks of TNBC are excessive proliferation and high metastasis of cancer cells. Increasing evidence has shown that the metastasis of TNBC cells mainly involves invasion, migration and angiogenesis, and the invasion is considered as the key step in metastasis process. SFAC markedly inhibited the invasion of MDA-MB-231 cells, and its anti-invasion potency was superior to that of inhibition of proliferation,

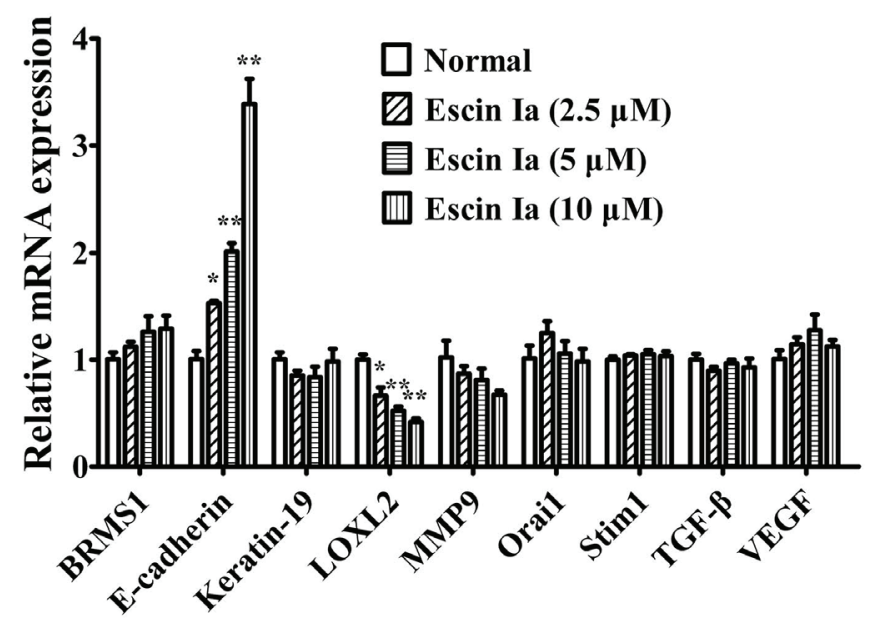

Figure 3: Effect of escin Ia on invasion-related factors in MDA-MB-231 cells. MDA-MB-231 cells were treated with escin Ia $(2.5,5,10 \mu \mathrm{M})$ for $24 \mathrm{~h}$, and the mRNA expressions of breast cancer metastasis suppressor 1 (BRMS1), E-cadherin, Keratin19, lysyl oxidase-like 2 (LOXL2), metal matrix proteinase 9 (MMP9), calcium release-activated calcium channel protein 1 (Orai1), stromal interaction molecule 1 (Stim1), transforming growth factor (TGF- $\beta$ ) and vascular endothelial growth factor (VEGF) were measured by using Q-PCR assay. Gene expressions were normalized to GAPDH. The data were expressed as the means \pm S.E.M. of three independent experiments. ${ }^{*} p<0.05,{ }^{* *} p<0.01 v s$. normal. 
apoptosis, migration and angiogenesis. It was suggested that invasion inhibition was the major mechanism for SFAC suppressing TNBC metastasis. In the present study, escin Ia, which showed stronger inhibition of the invasion of MDA-MB-231 cells than other five saponin ingredients isolated from SFAC, was proven to be the major antiinvasion active constituent of SFAC.

Invasion can be regulated by a variety of factors such as BRMS1, E-cadherin, Keratin19, LOXL2, MMP9,
Orail, Stim1, TGF- $\beta$ and VEGF. These factors with lower or higher expressions are associated with poor prognosis of TNBC patients. Therefore, the abrogation of the expressions of the aberrant factors may inhibit invasion and TNBC metastasis, and can be considered as a good strategy for TNBC therapy [20-26]. Our study showed that escin Ia obviously inhibited invasion of MDAMB-231 cells in vitro, and prevented lung metastasis of MDA-MB-231 xenograft model in vivo. In addition, escin
A

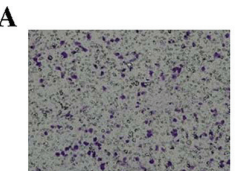

Normal

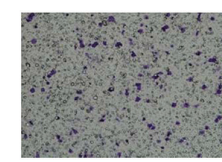

B

Escin Ia $(5 \mu \mathrm{M}) \quad$ Escin Ia $(10 \mu \mathrm{M})$

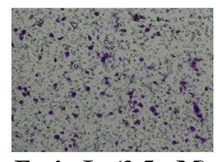

Escin Ia $(2.5 \mu \mathrm{M})$

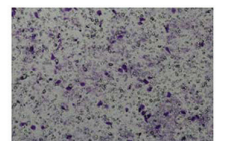

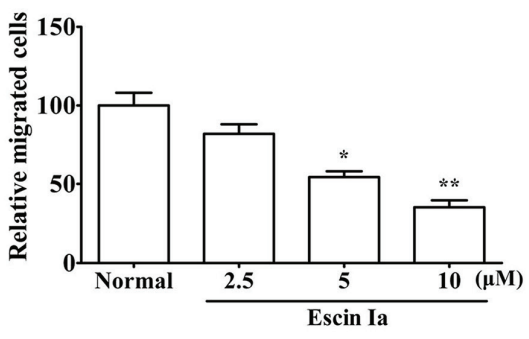

Escin Ia $(\mu M) \quad 0 \quad 2.5 \quad 5 \quad 10$

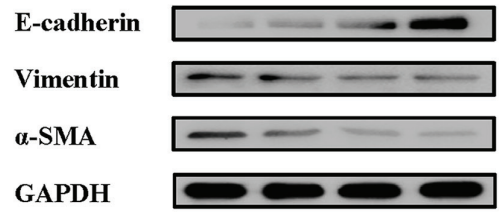

C

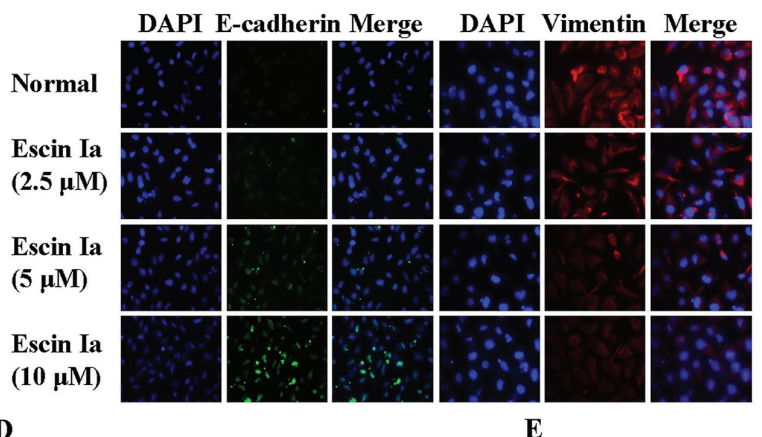

D
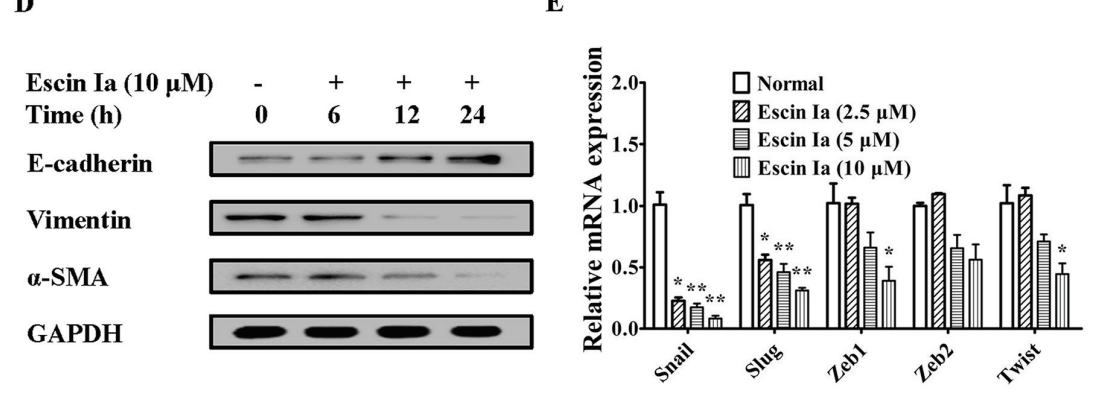

Figure 4: Effect of escin Ia on epithelial-mesenchymal transition in MDA-MB-231 cells. MDA-MB-231 cells were treated with escin Ia $(2.5,5,10 \mu \mathrm{M})$ for the indicated intervals. (A) Cell migration was detected by using cell migration assay. The number of cells migrated through the bottom chambers were counted in three different regions. (B) The protein expressions of E-cadherin, vimentin and $\alpha$-SMA were detected by using western blot analysis. (C) The protein expressions of E-cadherin and vimentin were detected by using immunofluorescence assay. (D) Time course of escin Ia on protein expressions of E-cadherin, vimentin and $\alpha$-SMA were detected by using western blot analysis. (E) The mRNA expressions of Snail, Slug, Zeb1, Zeb2 and Twist were detected by using Q-PCR assays. Gene expressions were normalized to GAPDH. The data were expressed as the means \pm S.E.M. of three independent experiments. ${ }^{*} p<0.05$, $* * p<0.01$ vs. normal. 
Ia markedly decreased mRNA expression of LOXL2 and increased mRNA expression of E-cadherin but not the other invasion-related factors, which indicated that LOXL2 and E-cadherin are important in escin Ia-mediated inhibition of MDA-MB-231 cell invasion.
EMT is a developmental and continuous process, and has been identified as the beginning of metastasis of cancers including TNBC [27]. Indeed, overexpression of EMT markers in breast cancer biopsies correlates with tumor aggressiveness, adverse clinicopathological

\section{A}

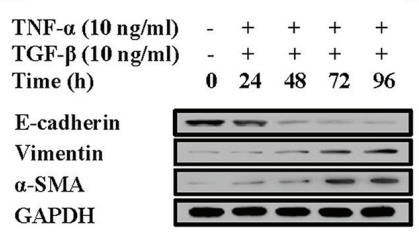

D

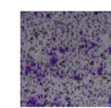

Normal TNF- $\alpha(10 \mathrm{ng} / \mathrm{ml})$ Escin Ia

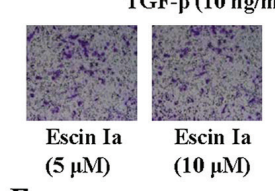

F

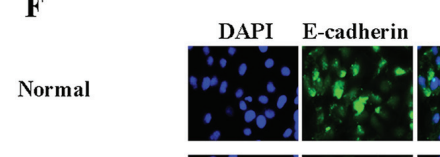

TNF- $\alpha(10 \mathrm{ng} / \mathrm{ml})$ TGF- $\beta(10 \mathrm{ng} / \mathrm{ml})$

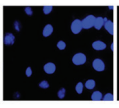

Escin Ia $(2.5 \mu \mathrm{M})$

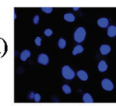

Escin Ia $(5 \mu \mathrm{M})$

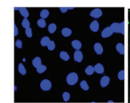

Escin Ia $(10 \mu \mathrm{M})$

G
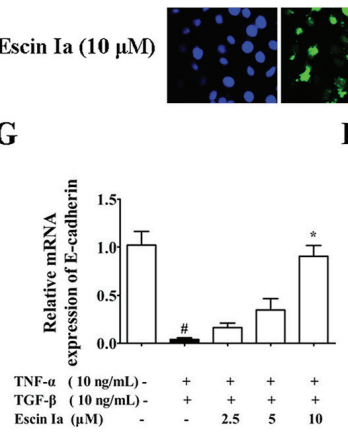

H
B

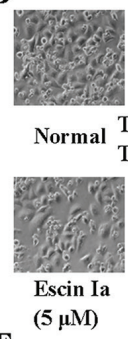

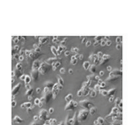

NF- $\alpha(10 \mathrm{ng} / \mathrm{ml})$ Escin I TGF- $\beta(10 \mathrm{ng} / \mathrm{ml})(2.5 \mu \mathrm{M})$

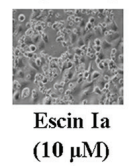

C

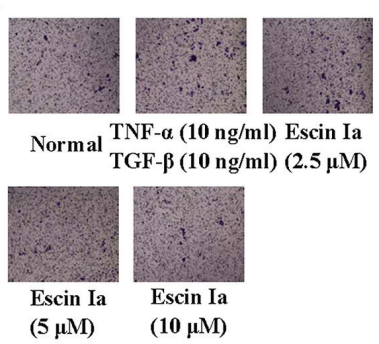

TNF- $\alpha(10 \mathrm{ng} / \mathrm{ml})-++++$

TGF- $\beta(10 \mathrm{ng} / \mathrm{ml})-++++$

$\operatorname{Escin} \mathrm{Ia}(\mu \mathrm{M}) \quad-\quad-2.5 \quad 5 \quad 10$

E-cadherin

Vimentin

$\alpha$-SMA

GAPDH
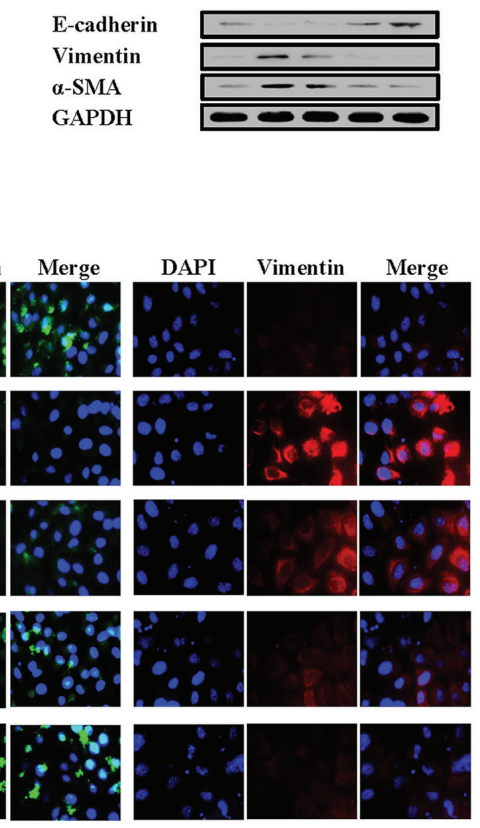

I

$\mathrm{TNF}-\boldsymbol{\alpha}(10 \mathrm{ng} / \mathrm{ml})-++++$

TGF- $\beta(10 \mathrm{ng} / \mathrm{ml})-++++$

Escin Ia $(10 \mu \mathrm{M})-+++$

$\begin{array}{llllll}\text { Time (h) } & 0 & 0 & 6 & 12 & 24\end{array}$

E-cadherin

Vimentin

a-SMA

GAPDH

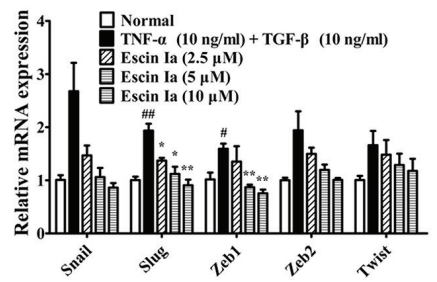

Figure 5: Effect of escin Ia on epithelial-mesenchymal transition in TNF- $\alpha$ /TGF- $\beta$-stimulated MCF-7 cells. (A) MCF-7 cells were treated with TNF- $\alpha+$ TGF- $\beta(10 \mathrm{ng} / \mathrm{mL}$ of each) for $0 \mathrm{~h}, 24 \mathrm{~h}, 48 \mathrm{~h}, 72 \mathrm{~h}, 96 \mathrm{~h}$, and the total protein lysates were immunoblotted for E-cadherin, vimentin and $\alpha$-SMA expressions. B-I, MCF-7 cells were incubated with TNF- $\alpha+\mathrm{TGF}-\beta$ (10 ng/mL of each) plus escin Ia $(2.5,5,10 \mu \mathrm{M})$ or escin Ia $(10 \mu \mathrm{M})$ for the indicated internals. Cell morphology was recorded under an inverted microscope (magnification $200 \times)($ B). Cell invasion was detected by using cell invasion assays (C). Cell migration was detected by using cell migration assay (D). The protein expressions ofE-cadherin, vimentin and $\alpha$-SMAwere detected by using western blot analysis $(\mathbf{E})$. The protein expressions ofE-cadherin and vimentin were detected by using immunofluorescence assay (F). The mRNA expressions of E-cadherin, Snail, Slug, Zeb1, Zeb2, Twist were detected by using Q-PCR assay $(\mathbf{G}, \mathbf{I})$. Gene expressions were normalized to GAPDH. Time course of escin Ia on protein expressions of E-cadherin, vimentin and $\alpha$-SMA were detected by using western blot analysis $(\mathbf{H})$. The data were expressed as the means \pm S.E.M. of three independent experiments. ${ }^{*} p<0.05,{ }^{* \#} p<0.01 v s$. normal; ${ }^{*} p<0.05,{ }^{* *} p<0.01 v s$. TNF- $\alpha(10 \mathrm{ng} / \mathrm{mL})+\mathrm{TGF}-\beta(10 \mathrm{ng} / \mathrm{mL})$. 
characteristics, increased recurrence, and shorter survival. Therefore, it may be of great therapeutic interest to develop effective therapeutic strategies to suppress EMT in TNBC cells to prevent its invasion. EMT process can be promoted by a lot of important transcription factors, such as Snail, Slug, Zeb1, Zeb2 and Twist [28]. These factors with higher expression are associated with poor prognosis of TNBC patients. In addition, the factors are

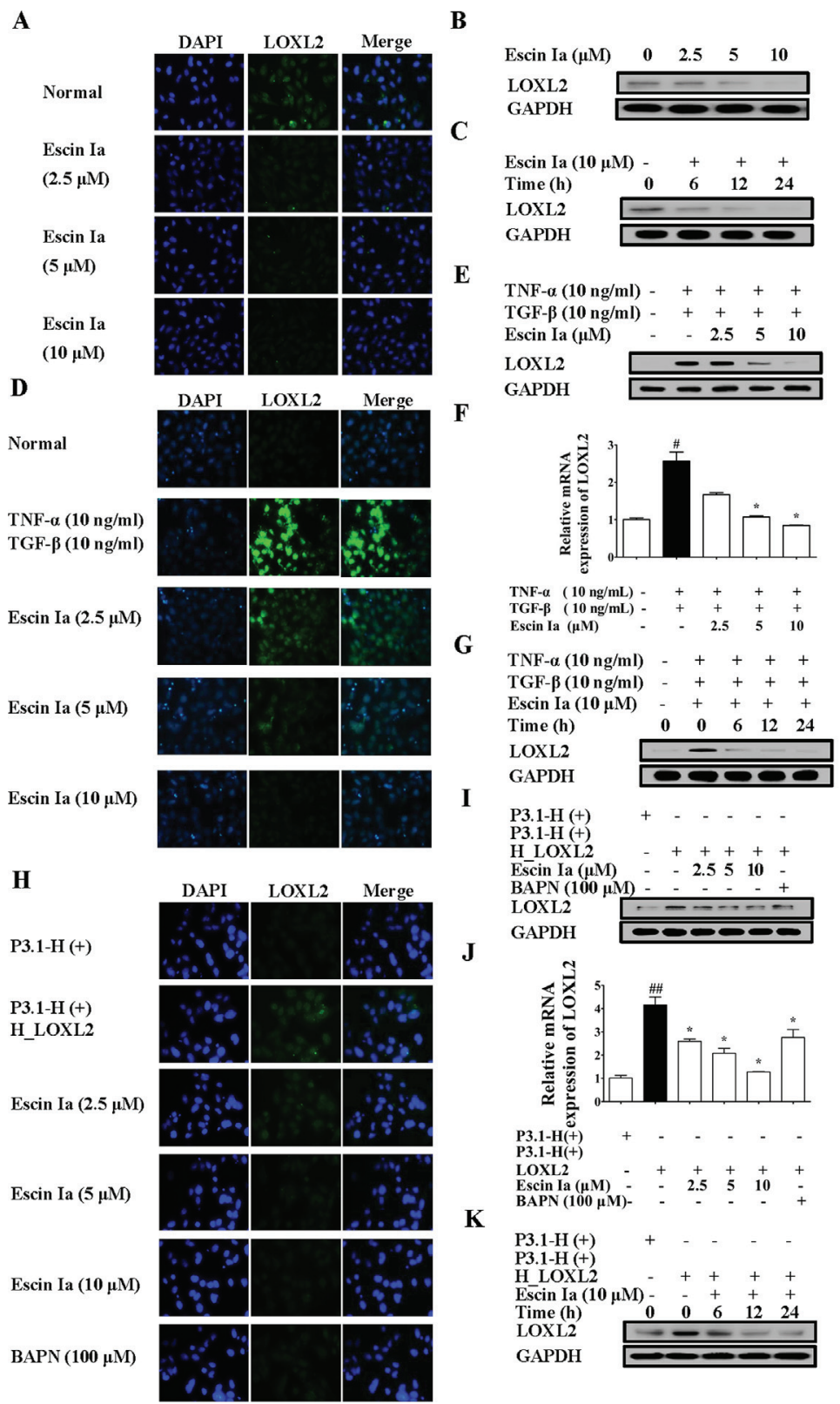

Figure 6: Effect of escin Ia on LOXL2 expression in MDA-MB-231 cells and TNF- $\alpha$ /TGF- $\beta$-stimulated or LOXL2transfected MCF-7 cells. (A-C) Effect of escin Ia on LOXL2 expression in MDA-MB-231 cells. MDA-MB-231 cells were treated with escin Ia $(2.5,5,10 \mu \mathrm{M})$ or escin Ia $(10 \mu \mathrm{M})$ for the indicated intervals. The protein expression of LOXL2 was detected by using immunofluorescence and western blot analysis (A, B). Time course of escin Ia on protein expression of LOXL2 was detected using western blot analysis (C); D-G, MCF-7 cells were incubated with TNF- $\alpha+$ TGF- $\beta$ (10 ng/mL of each) plus escin Ia $(2.5,5,10 \mu \mathrm{M})$ or escin Ia $(10 \mu \mathrm{M})$ for the indicated internals. The protein and mRNA expression of LOXL2 was detected by using immunofluorescence, western blot and Q-PCR assays (D-F). Time course of escin Ia on protein expression of LOXL2 was detected using western blot analysis (G); H-K, MCF-7 cells were transiently transfected with a plasmid of LOXL2 (P3.1-H (+) H_LOXL2) plus escin Ia $(2.5,5,10 \mu \mathrm{M})$, BAPN (100 $\mu$ M) or escin Ia $(10 \mu \mathrm{M})$ for the indicated internals. The protein expression of LOXL2 was detected by using immunofluorescence assays, western blot analysis and Q-PCR assays $(\mathbf{H}-\mathbf{J})$. Time course of escin Ia on protein expression of LOXL2 was detected by using western blot analysis (K). The data were expressed as the means \pm S.E.M. of three independent experiments. ${ }^{*} p<0.05 v s$. TNF $-\alpha(10 \mathrm{ng} / \mathrm{mL})+\mathrm{TGF}-\beta(10 \mathrm{ng} / \mathrm{mL})$, ${ }^{\# \#} p<0.01$ vs. p3.1-H (+); ${ }^{*} p<0.05$ vs. TNF- $\alpha(10 \mathrm{ng} / \mathrm{mL})+\mathrm{TGF}-\beta(10 \mathrm{ng} / \mathrm{mL}),{ }^{*} p<0.05$ vs. p3.1-H(+) H_LOXL2. 
highly expressed in MDA-MB-231 cells. Thus, reduction of the factors is a good method for EMT inhibition [29-35]. Our present study showed that EMT process of MDA-MB-231 cells and TNF- $\alpha /$ TGF- $\beta$-stimulated MCF7 cells were significantly inhibited by escin Ia treatment. In addition, escin Ia suppressed EMT process in MDAMB-231 xenograft model. These findings indicated that
EMT inhibition was an important mechanism for the antiinvasion effect of escin Ia on TNBC.

LOXL2 encodes an extracellular copper-dependent amine oxidase, and it is over-expressed in various types of primary cancer tissues and cells. Importantly, increasing evidence indicates that high LOXL2 expression correlates with tumor grade and poor survival. Therefore, reduction
A

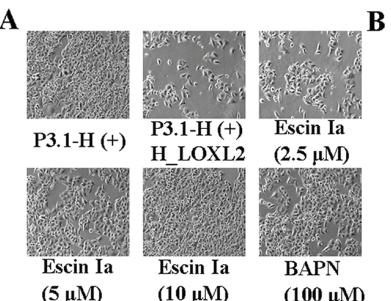

B

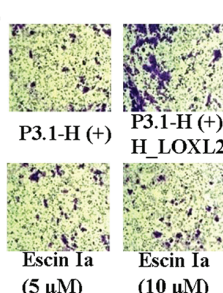

C

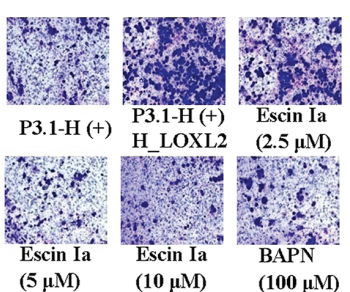

D

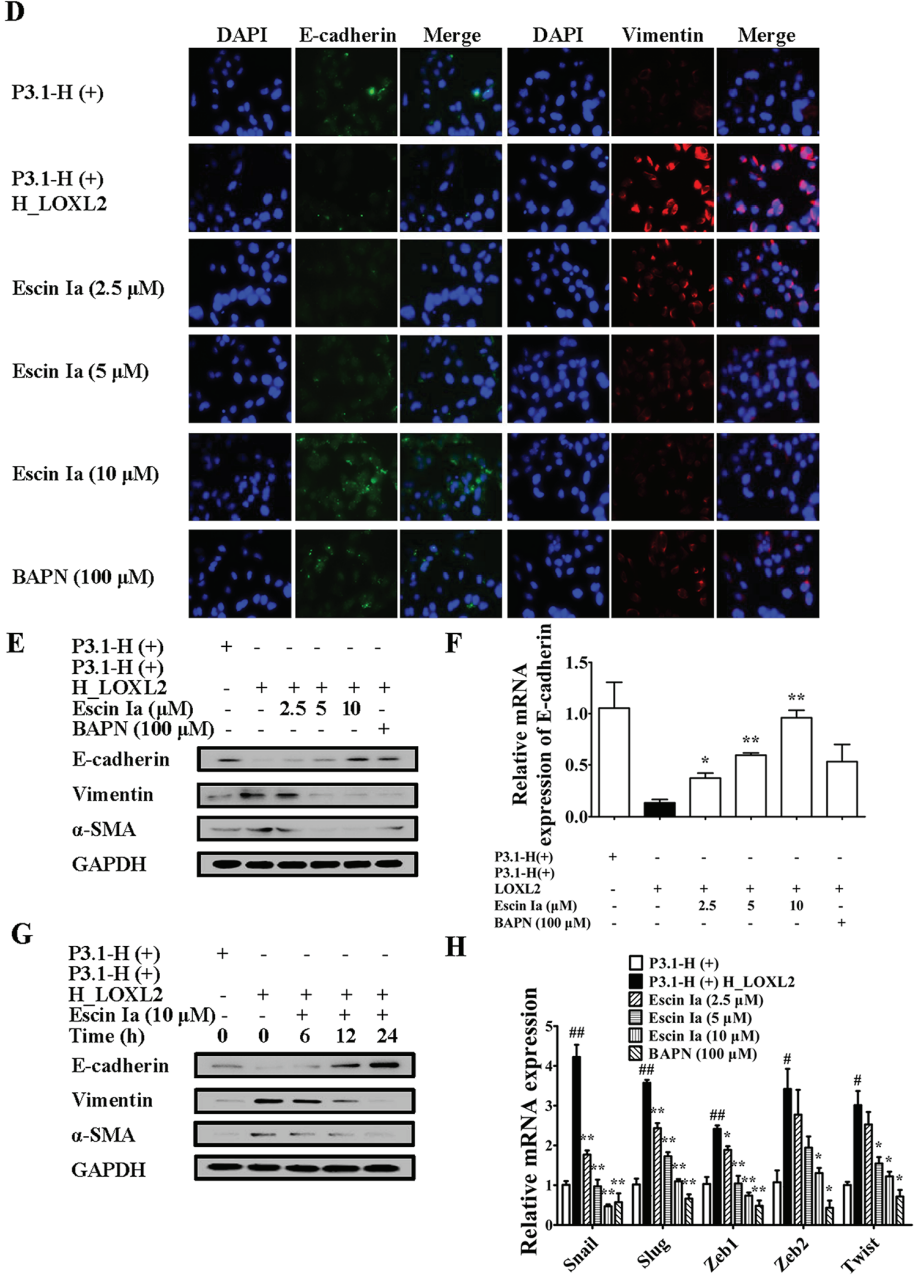

Figure 7: Effect of escin Ia on epithelial-mesenchymal transition in LOXL2-transfected MCF-7 cells. MCF-7 cells were transfected with a plasmid of LOXL2 (P3.1-H (+) H_LOXL2) plus escin Ia $(2.5,5,10 \mu \mathrm{M})$ or escin Ia $(10 \mu \mathrm{M})$ for the indicated internals. (A) Cell morphology was recorded under an inverted microscope (magnification $200 \times$ ). (B) Cell invasion was detected by using cell invasion assay. (C) Cell migration was detected by using cell migration assay. (D) The protein expressions of E-cadherin and vimentin were detected by using immunofluorescence assay. (E) The protein expressions of E-cadherin, vimentin and $\alpha$-SMA were detected using western blot analysis. (F, H) The mRNA expressions of E-cadherin, Snail, Slug, Zeb1, Zeb2 and Twist were detected using Q-PCR assays. Gene expressions were normalized to GAPDH. (G) Time course of escin Ia on protein expressions of E-cadherin, vimentin and $\alpha$-SMA were detected by using western blot analysis. The data were expressed as the means \pm S.E.M. of three independent experiments. ${ }^{*} p<0.05$, ${ }^{\#} p<0.01$ vs. p3.1-H(+); ${ }^{*} p<0.05,{ }^{* *} p<0.01$ vs. p3.1-H(+) H_LOXL2. 
of LOXL2 expression may be an effective approach for TNBC therapy [36-38]. Our data showed that escin Ia markedly decreased LOXL2 expression of MDAMB-231 cells, and abrogated the increase of LOXL2 expression induced by TNF- $\alpha /$ TGF- $\beta$ stimulation, LOXL2 transfection or hypoxia in MCF-7 cells. Furthermore, LOXL2 expression was also down-regulated by escin Ia treatment in MDA-MB-231 xenograft model. However, escin Ia showed slight effect on LOXL2 expression and EMT process in MCF-7 cells. It was a remarkable fact that LOXL 2 but not E-cadherin, vimentin, $\alpha$-SMA expressions was down-regulated by escin Ia treatment for $6 \mathrm{~h}$ in MDA-
MB-231 cells and MCF-7 cells treated with TNF- $\alpha$ / TGF- $\beta$. These findings suggested that escin Ia might suppress EMT process through LOXL2. Based on these findings, we further investigated the relationship between the reduction of LOXL2 expression and inhibition of EMT process by escin Ia. The results showed that EMT process of LOXL2-transfected MCF-7 cells was significantly inhibited by escin Ia treatment for $6 \mathrm{~h}$, which was accompanied by a decrease of the expression of LOXL2 but not E-cadherin, vimentin and $\alpha$-SMA. Moreover, escin Ia markedly reduced LOXL2 expression and suppressed EMT process in hypoxia-stimulated MCF-7 cells. These
A

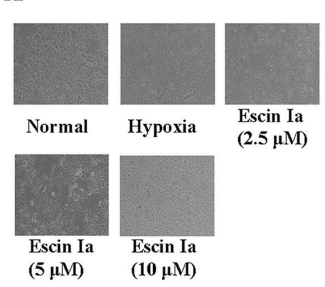

B

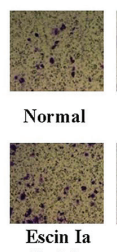

C

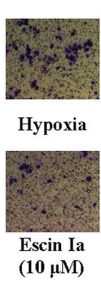

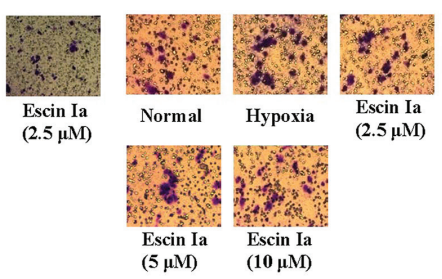

D

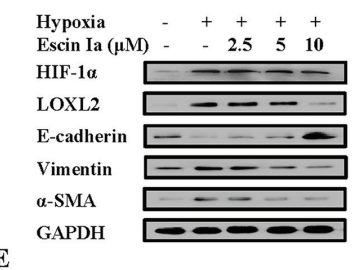

$\mathbf{E}$

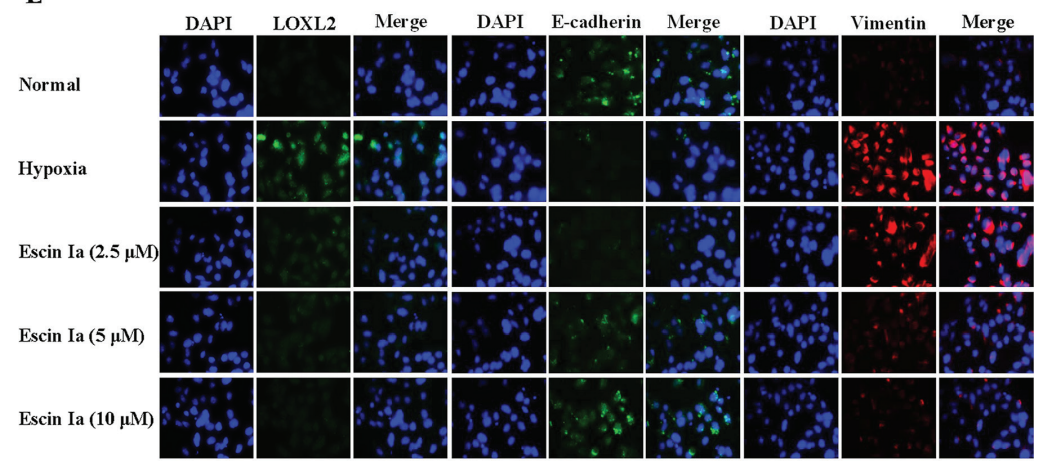

$\mathbf{F}$

G
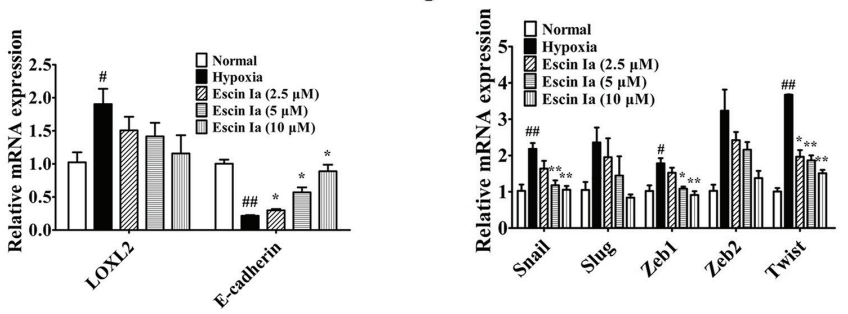

Figure 8: Effect of escin Ia on epithelial-mesenchymal transition in hypoxia-stimulated MCF-7 cells. MCF-7 cells were incubated with hypoxia plus escin Ia $(2.5,5,10 \mu \mathrm{M})$ for the indicated internals. (A) Cell morphology was recorded under an inverted microscope (magnification $200 \times$ ). (B) Cell invasion was detected by using cell invasion assay. (C) Cell migration was detected by using cell migration assay. (D) The protein expressions of HIF-1 $\alpha$, LOXL2, E-cadherin, vimentin and $\alpha$-SMA were detected by using western blot analysis. (E) The protein expressions of LOXL2, E-cadherin and vimentin were detected by using immunofluorescence assay. (F, G) The mRNA expressions of LOXL2, E-cadherin, Snail, Slug, Zeb1, Zeb2 and Twist were detected by using Q-PCR assay. Gene expressions were normalized to GAPDH. The data were expressed as the means \pm S.E.M. of three independent experiments. ${ }^{\#} p<0.05$, ${ }^{\#} p<0.01 v s$. normal; ${ }^{*} p<0.05, * * p<0.01$ vs. hypoxia. 
findings strongly suggested that escin Ia suppressed EMT process through LOXL2, and resulted in the inhibition of TNBC invasion.

HIF-1 $\alpha$, a master transcriptional regulator of cellular and developmental response to hypoxia, was proven to facilitate invasion and metastatic niche formation [39]. In MDA-MB-231 cells, knockdown of HIF-1 $\alpha$ blocked hypoxia-induced expression of LOXL2, which indicated that HIF-1 $\alpha$ located at the upstream of LOXL2 [40]. Our present data showed that escin Ia showed little effect on HIF-1 $\alpha$ expression in MDA-MB-231 cells (data not shown) and hypoxia-stimulated MCF-7 cells. Consistently, escin Ia showed slight effect on HIF-1 $\alpha$ expression in MDA-MB-231 xenograft mice.

In conclusion, escin Ia is the major active constituent of SFAC for its inhibitory effect on the invasion of TNBC, and it functions by inhibition of EMT process via downregulating LOXL2 expression.

A

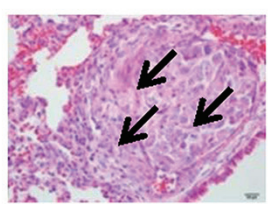

Control

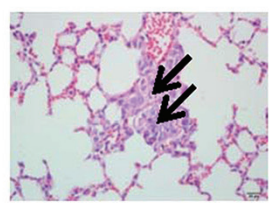

Escin Ia

(4 mg/kg)

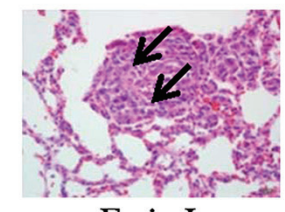

Escin Ia

$(2 \mathrm{mg} / \mathrm{kg})$

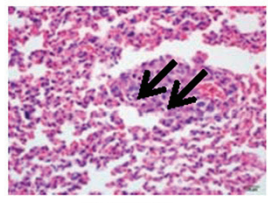

BAPN

(100 m g/kg)
C

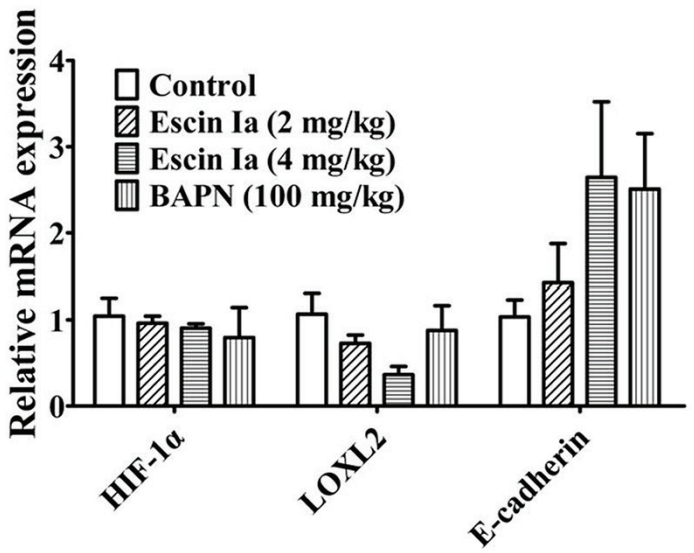

\section{MATERIALS AND METHODS}

\section{Reagents}

SFAC (containing saponin constituents higher than $74.4 \%)$, escin Ia $\left(\mathrm{C}_{55} \mathrm{H}_{86} \mathrm{O}_{24}, \mathrm{MW}: 1131.26\right.$, purity $\geq$ $98 \%)$, escin $\mathrm{Ib}\left(\mathrm{C}_{55} \mathrm{H}_{86} \mathrm{O}_{24}, \mathrm{MW}: 1131.26\right.$, purity $\left.\geq 98 \%\right)$, escin IIa $\left(\mathrm{C}_{54} \mathrm{H}_{84} \mathrm{O}_{23}, \mathrm{MW}: 1101.23\right.$, purity $\left.\geq 98 \%\right)$, escin IIb $\left(\mathrm{C}_{54} \mathrm{H}_{84} \mathrm{O}_{23}, \mathrm{MW}: 1101.23\right.$, purity $\left.\geq 98 \%\right)$, escin IIIa $\left(\mathrm{C}_{55} \mathrm{H}_{86} \mathrm{O}_{23}, \mathrm{MW}: 1115.26\right.$, purity $\left.\geq 98 \%\right)$ and escin IIIb $\left(\mathrm{C}_{55} \mathrm{H}_{86} \mathrm{O}_{23}, \mathrm{MW}: 1115.26\right.$, purity $\left.\geq 98 \%\right)$ were obtained from Yinxing Pharmaceutical Technology Co., Ltd. (Nanjing, China) (Figure 1); $\beta$-aminopropionitrile (BAPN) was obtained from Sa'en Co., Ltd. (Shanghai, China); Transforming growth factor- $\beta$ (TGF- $\beta$ ) and tumor necrosis factor- $\alpha$ (TNF- $\alpha)$ were obtained from R \& D Systems (Minneapolis, USA); TRIzol and Lipofectamine 2000

B

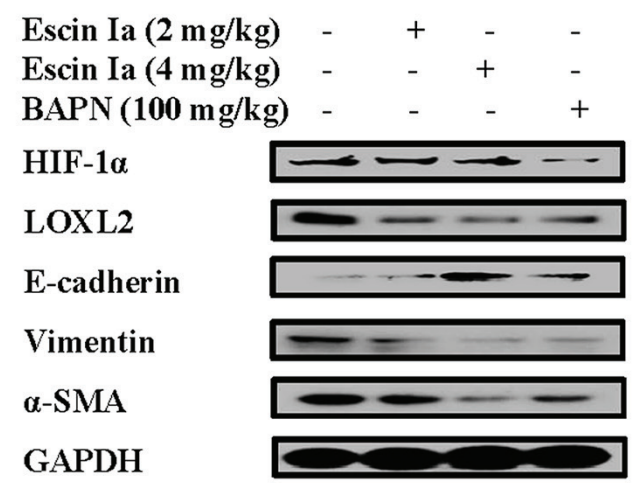

D

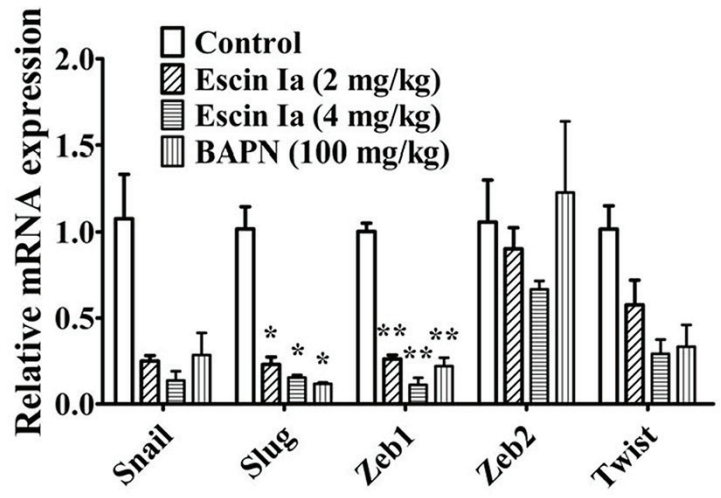

Figure 9: Effect of escin Ia on lung metastasis of MDA-MB-231 xenograft model in vivo. Mice were injected with MDAMB-231 cells at the left and right mammary fat pads, and then treated with escin Ia (2, $4 \mathrm{mg} / \mathrm{kg})$ and BAPN (100 mg/kg) for five weeks. (A) H \& E staining was used for detecting metastatic tumor cells in mouse lungs. Arrows indicated infiltration of tumor cells. (B) Tumor samples from the breasts of mice were collected at the end of five weeks and subjected to western blot analysis for HIF-1 $\alpha$, LOXL2, E-cadherin, vimentin and $\alpha$-SMA expressions. (C, D) Tumor samples from breast of mice were collected at the end of five weeks and subjected to Q-PCR assays for HIF-1 $\alpha$, LOXL2, E-cadherin, Snail, Slug, Zeb1, Zeb2 and Twist mRNA expressions. Gene expressions were normalized to GAPDH. The data were expressed as the means \pm S.E.M. of three independent experiments. ${ }^{*} p<0.05,{ }^{* *} p<0.01 v s$. control. 
reagents were obtained from Invitrogen (Carlsbad, USA); E-cadherin and LOXL2 antibodies were purchased from Genetex (Irvine, USA); HIF-1 $\alpha$ and vimentin antibodies were purchased from BioWorld (Georgia, USA); $\alpha$-SMA antibody was purchased from Abcam (Cambridge, UK); GAPDH monoclonal antibody was purchased from KangChen Bio-tech (Shanghai, China); HRP-conjugated secondary antibodies were purchased from Abbkine (Redlands, USA); Fetal bovine serum (FBS) was obtained from PAA (Linz, Germany). Other analytical reagent grade chemicals were obtained from Sinopharm Chemical Reagent Co. Ltd (Nanjing, China).

\section{Cell culture}

MDA-MB-231 cells and MCF-7 cells were obtained from American Type Culture Collection (ATCC, Manassas, VA, USA), and cultured in a humidified incubator at $37^{\circ} \mathrm{C}$ under $5 \% \mathrm{CO}_{2}$ atmospheric condition in corresponding medium Supplementaryed with 10\% FBS, $100 \mathrm{U} / \mathrm{mL}$ streptomycin and $100 \mathrm{U} / \mathrm{mL}$ penicillin.

\section{Cell transfection}

The plasmid expressing a constitutively active form of LOXL2 was purchased from Jiman Biochemical Technology Co., Ltd (Shanghai, China). MCF-7 cells were transfected with LOXL2 by using Lipofectamine 2000 (Invitrogen, Carlsbad, USA) according to manufacturer's instructions.

\section{Cell migration assay}

Cell migration assay was carried out by using transwell plates (Millipore, Billerica, USA) as described previously with a little modification. MDA-MB-231 cells and MCF-7 cells were transfected with LOXL2, stimulated with TNF- $\alpha /$ TGF- $\beta$ or hypoxia (a modified incubator chamber flushed with a gas mixture containing $1 \% \mathrm{O}_{2}, 94 \% \mathrm{~N}_{2}$ and $5 \% \mathrm{CO}_{2}$ in a humidified atmosphere). Then, they were treated with escin Ia $(2.5,5,10 \mu \mathrm{M})$ or BAPN $(100 \mu \mathrm{M})$ for $6 \mathrm{~h}$, and detached and suspended in culture medium. Then, cells $\left(1 \times 10^{4}\right.$ cells/well $)$ was added into the upper chamber of the transwell plates, while the lower chamber was full of $600 \mu \mathrm{L}$ culture medium with $10 \%$ FBS as a chemoattractant. After being incubated for $6 \mathrm{~h}$ at $37^{\circ} \mathrm{C}$, the non-migrated cells on the upper surface of the membrane were removed by soaked cotton swab. In addition, the cells migrated to the bottom face of the membranes were counted after being stained with crystal violet solutions. Then, fields per filter were captured randomly at a magnification of $200 \times$ with Olympus IX51 inverted microscope.

\section{Tube formation assay}

Matrigel (150 $\mu \mathrm{L} /$ well) was added to 48 -well plates and allowed to polymerize for $1 \mathrm{~h}$. Human umbilical vein endothelial cells (HUVECs, MaiGaoQiao Hospital, Nanjing, China) were suspended and added into each well $\left(8 \times 10^{4}\right.$ cells/well $)$ together with indicated concentrations of SFAC. The capillary tube formations were visualized after $24 \mathrm{~h}$. The images were captured by an Olympus IX51 inverted microscope using a $100 \times$ objective lens. The tube formation was defined by measuring the branch length of the formed tubes.

\section{Cell invasion assay}

Cell invasion assay was performed by using transwell chamber with $10 \mathrm{~mm}$ diameter and $8 \mu \mathrm{m}$ pore size polycarbonate membrane (Corning Costar, Cambridge, UK) coated with matrigel as previously described. MDA-MB-231 cells and MCF-7 cells, transfected with LOXL2 or stimulated with TNF- $\alpha /$ TGF- $\beta$ or hypoxia, were treated with escin Ia $(2.5,5,10 \mu \mathrm{M})$ or escin Ib-IIIb $(5 \mu \mathrm{M})$ or BAPN $(100 \mu \mathrm{M})$ for $24 \mathrm{~h}$, and detached and suspended in culture medium. An aliquot $(200 \mu \mathrm{L})$ of cells $\left(1 \times 10^{5}\right.$ cells $\left./ \mathrm{mL}\right)$ was added into the upper chamber of the transwell, while the lower chamber was full of $600 \mu \mathrm{L}$ medium with $10 \%$ FBS as a chemoattractant. After being incubated for $24 \mathrm{~h}$ at $37^{\circ} \mathrm{C}$, the non-invaded cells on the upper surface of the membrane were removed by soaked cotton swab, and the cells invaded to bottom face of the membranes were counted after being stained with crystal violet solutions. Then, fields per filter were captured randomly at a magnification of $200 \times$ with Olympus IX51 inverted microscope.

\section{Quantitative real-time polymerase chain reaction (Q-PCR)}

MDA-MB-231 cells, MCF-7 cells transfected with LOXL 2 or stimulated with TNF- $\alpha /$ TGF- $\beta$ or hypoxia were treated with escin Ia or BAPN, and the total RNA were isolated by using TRIzol reagent according to the supplier's instructions. The cDNA was transcribed from RNA by using HiScript RT Super Mix (Vazyme, Nanjing, China), then analyzed for the expressions of Snail, Slug, Zeb1, Zeb2, Twist, LOXL2, hypoxia-inducible factor 1-alpha (HIF-1 $\alpha$ ), E-cadherin, breast cancer metastasis suppressor 1 (BRMS1), metal matrix proteinase 9 (MMP9), calcium release-activated calcium channel protein 1 (Orai1), stromal interaction molecule 1 (Stim1), Keratin19, TGF- $\beta$ and VEGF by Ace Q-PCR SYBR Green Master Mix (Vazyme, Nanjing, China) with the help of MyiQ2 Detection System (Bio-Rad Laboratories, Hercules, USA). The primer sequences used were listed in Table 1: 
Table 1: Primer pairs used in quantitative real-time PCR

\begin{tabular}{|c|c|c|c|}
\hline Genc & & sequence $\left(5^{\prime}-3^{\prime}\right)$ & Length (bp) \\
\hline \multirow[t]{2}{*}{ GAPDH } & forward & AGAAGGCTGGGGCTCATTTG & 258 \\
\hline & reverse & AGGGGCCATCCACAGTCTTC & \\
\hline \multirow[t]{2}{*}{ VEGF } & forward & CTACCTCCACCATGCCAAGT & 187 \\
\hline & reverse & CACACAGGATGGCTTGAAGA & \\
\hline \multirow[t]{2}{*}{ MMP9 } & forward & CTACCACCTCGAACTTTGAC & 161 \\
\hline & reverse & CTCAGTGAAGCGGTACATAG & \\
\hline \multirow[t]{2}{*}{ TGF- $\beta$} & forward & GGCCCTGCCCCTACATTT & 75 \\
\hline & reverse & CCGGGTTATGCTGGTTGTACA & \\
\hline \multirow[t]{2}{*}{ E-cadherin } & forward & GACCGAGAGAGTTTCCCTACG & 158 \\
\hline & reverse & TCAGGCACCTGACCCTTGTA & \\
\hline \multirow[t]{2}{*}{ Keratin19 } & forward & GATGAGCAGGTCCGAGGTTAC & 106 \\
\hline & reverse & TGCCAGTGTGTCTTCCAAGG & \\
\hline \multirow[t]{2}{*}{ Orail } & forward & ACGTGCACAATCTCAACTCG & 121 \\
\hline & reverse & AGCACCACCTCAGCTAGGAAG & \\
\hline \multirow[t]{2}{*}{ Stim1 } & forward & СТCСТCTCTTGACTCGCCAT & 154 \\
\hline & reverse & CGGTGTAACCCCTCCAAGTC & \\
\hline \multirow[t]{2}{*}{ LOXL2 } & forward & GTGGATCTGGCACGACTGTCA & 75 \\
\hline & reverse & TTGAGGTTCAGCAGGTCATAGTGG & \\
\hline \multirow[t]{2}{*}{ BRMS1 } & forward & ATGCCTGTCCAGCCTCCAAG & 168 \\
\hline & reverse & GCGTCGCTCATAGTCCTCATCA & \\
\hline \multirow[t]{2}{*}{ HIF-1 $1 \alpha$} & forward & CCCATTAGCAGGTGAAGGAA & 141 \\
\hline & reverse & CCAGAATCAAACCAAACCAA & \\
\hline \multirow[t]{2}{*}{ Snail } & forward & CCCCAATCGGAAGCCTAACT & 71 \\
\hline & reverse & CGTAGGGCTGCTGGAAGGTA & \\
\hline \multirow[t]{2}{*}{ Slug } & forward & CCATTCCACGCCCAGCTA & 71 \\
\hline & reverse & CTCACTCGCCCCAAAGATGA & \\
\hline \multirow[t]{2}{*}{ Twist } & forward & GGAGTCCGCAGTCTTACGAG & 201 \\
\hline & reverse & TCTGGAGGACCTGGTAGAGG & \\
\hline \multirow[t]{2}{*}{ Zeb1 } & forward & ATGCGGAAGACAGAAAATGG & 297 \\
\hline & reverse & GTCACGTTCTTCCGCTTCTC & \\
\hline \multirow[t]{2}{*}{ Zeb2 } & forward & AACAACGAGATTCTACAAGCCTC & 176 \\
\hline & reverse & TCGCGTTCCTCCAGTTTTCTT & \\
\hline
\end{tabular}




\section{Western blotting}

MDA-MB-231 cells and MCF-7 cells transfected with LOXL2 or stimulated with TNF- $\alpha$ /TGF- $\beta$ or hypoxia were treated with escin Ia or BAPN, and the total cell lysates were prepared by using NP40 buffer (Beyotime, Nanjing, China). The equal concentration of protein lysate of all the samples was separated on $8 \%$ SDS-PAGE gel and further transferred to PVDF membranes. The membranes were blocked with $5 \%$ non-fat milk for $2 \mathrm{~h}$, and incubated with specific primary antibodies overnight at $4{ }^{\circ} \mathrm{C}$. After being washed with TBS- $0.1 \%$ Tween, membranes were incubated with HRP-conjugated anti-mouse or anti-rabbit $\operatorname{IgG}$ secondary antibodies, and then visualized with ECL reagent (Guge Biochemical Technology Co., Ltd., Wuhan, China).

\section{Immunofluorescence assay}

MDA-MB-231 cells and MCF-7 cells $\left(2 \times 10^{3}\right.$ cells $/ \mathrm{mL}$ ) transfected with LOXL2, stimulated with TNF- $\alpha /$ TGF- $\beta$ or hypoxia, were treated with escin Ia or BAPN, and then detached, re-suspended and plated into 96-well chamber slides (Millipore, Billerica, USA). Cells were fixed and stained after incubation according to the supplier's instructions.

\section{Animals and treatment}

Female athymic nude mice, 4-6 week-old, were obtained from Cavens Laboratory Animals Co., Ltd. (Changzhou, China). All animal experiments were performed in strict accordance with the Guide for the Care and Use of Laboratory Animals.

MDA-MB-231 cells re-suspended in PBS $\left(1 \times 10^{7}\right.$ cells $/ \mathrm{mL}$ ) were injected subcutaneously into the left and right mammary fat pads of mice. Two weeks after initial implantation, mice were divided into four groups: 1) control group; 2) escin Ia (2 mg/kg) group; 3$)$ escin Ia $(4 \mathrm{mg} / \mathrm{kg})$ group; 4) BAPN (100 mg/kg) group. Escin Ia and BAPN were intraperitoneally injected three times per week for the duration of the experiment.

All animals were sacrificed after five weeks of treatments, and the tumors from the breasts of mice were collected and utilized for the detection of RNA and protein by using Q-PCR and western blotting assays, respectively.

\section{Statistical analysis}

The data were presented as the means \pm S.E.M. Statistical analysis was performed by using one-way analysis of variance (ANOVA) followed by Tukey's test. $P$ values less than $0.05(P<0.05)$ were accepted as a significant difference.

\section{ACKNOWLEDGMENTS AND FUNDING}

This work was supported by the Priority Academic Program Development of Jiangsu Higher Education Institutions.

\section{CONFLICTS OF INTEREST}

The authors have no financial conflicts of interest.

\section{REFERENCES}

1. DeSantis C, Ma J, Bryan L, Jemal A. Breast cancer statistics, 2013. CA Cancer J Clin. 2014; 64:52-62.

2. Munzone E, Colleoni M. Clinical overview of metronomic chemotherapy in breast cancer. Nat Rev Clin Oncol. 2015; 12:631-644.

3. Zardavas D, Baselga J, Piccart M. Emerging targeted agents in metastatic breast cancer. Nat Rev Clin Oncol. 2013; 10:191-210.

4. Wei F, Ma LY, Jin WT, Ma SC, Han GZ, Khan IA, Lin RC. Antiinflammatory triterpenoid saponins from the seeds of Aesculus chinensis. Chem Pharm Bull (Tokyo). 2004; 52:1246-1248.

5. Zhou Y, Hui X, Li N, Zhuang W, Liu G, Wu T, Wei M, Wu X. Saponins from Chinese Buckeye Seed reduce cerebral edema: metaanalysis of randomized controlled trials. Planta Med. 2005; 71:993-998.

6. Niu YP, Wu LM, Jiang YL, Wang WX, Li LD. Beta-escin, a natural triterpenoid saponin from Chinese horse chestnut seeds, depresses HL-60 human leukaemia cell proliferation and induces apoptosis. J Pharm Pharmacol. 2008; 60:12131220 .

7. Chen J, Li W, Yang B, Guo X, Lee FS, Wang X. Determination of four major saponins in the seeds of Aesculus chinensis Bunge using accelerated solvent extraction followed by high-performance liquid chromatography and electrospray-time of flight mass spectrometry. Anal Chim Acta. 2007; 596:273-280.

8. Smith PW, Liu Y, Siefert SA, Moskaluk CA, Petroni GR, Jones DR. Breast cancer metastasis suppressor 1 (BRMS1) suppresses metastasis and correlates with improved patient survival in non-small cell lung cancer. Cancer Lett. 2009; 276:196-203.

9. Mareel M, Boterberg T, Noë V, Van Hoorde L, Vermeulen S, Bruyneel E, Bracke M. E-cadherin/catenin/cytoskeleton complex: a regulator of cancer invasion. J Cell Physiol. 1997; 173:271-274.

10. Lehmann BD, Bauer JA, Chen $X$, Sanders ME, Chakravarthy AB, Shyr Y, Pietenpol JA. Identification of human triple-negative breast cancer subtypes and 
preclinical models for selection of targeted therapies. J Clin Invest. 2011; 121:2750-2767.

11. Ahn SG, Dong SM, Oshima A, Kim WH, Lee HM, Lee SA, Kwon SH, Lee JH, Lee JM, Jeong J, Lee HD, Green JE. LOXL2 expression is associated with invasiveness and negatively influences survival in breast cancer patients. Breast Cancer Res Treat. 2013; 141:89-99.

12. Mehner C, Hockla A, Miller E, Ran S, Radisky DC, Radisky ES. Tumor cell-produced matrix metalloproteinase 9 (MMP9) drives malignant progression and metastasis of basal-like triple negative breast cancer. Oncotarget. 2014; 5:2736-2749. doi: 10.18632/oncotarget.1932.

13. Motiani RK, Hyzinski-García MC, Zhang X, Henkel MM, Abdullaev IF, Kuo YH, Matrougui K, Mongin AA, Trebak M. STIM1 and Orail mediate CRAC channel activity and are essential for human glioblastoma invasion. Pflugers Arch. 2013; 465:1249-1260.

14. Jiang WG, Sanders AJ, Katoh M, Ungefroren H, Gieseler F, Prince M, Thompson SK, Zollo M, Spano D, Dhawan P, Sliva D, Subbarayan PR, Sarkar M, et al. Tissue invasion and metastasis: Molecular, biological and clinical perspectives. Semin Cancer Biol. 2015; 35: S244-S275.

15. Chekhonin VP, Shein SA, Korchagina AA, Gurina OI. VEGF in tumor progression and targeted therapy. Curr Cancer Drug Targets. 2013; 13:423-443.

16. Avtanski DB, Nagalingam A, Bonner MY, Arbiser JL, Saxena NK, Sharma D. Honokiol inhibits epithelialmesenchymal transition in breast cancer cells by targeting signal transducer and activator of transcription 3/Zeb1/Ecadherin axis. Mol Oncol. 2014; 8:565-580.

17. Canesin G, Cuevas EP, Santos V, López-Menéndez C, Moreno-Bueno G, Huang Y, Csiszar K, Portillo F, Peinado H, Lyden D, Cano A. Lysyl oxidase-like 2 (LOXL2) and E47 EMT factor: novel partners in E-cadherin repression and early metastasis colonization. Oncogene. 2015; 34:951-964.

18. Moon HJ, Finney J, Xu L, Moore D, Welch DR, Mure M. MCF-7 cells expressing nuclear associated lysyl oxidaselike 2 (LOXL2) exhibit an epithelial-to-mesenchymal transition (EMT) phenotype and are highly invasive in vitro. J Biol Chem. 2013; 288:30000-30008.

19. Semenza GL. Molecular mechanisms mediating metastasis of hypoxic breast cancer cells. Trends Mol Med. 2012; 18:534-543.

20. Samant RS, Seraj MJ, Saunders MM, Sakamaki TS, Shevde LA, Harms JF, Leonard TO, Goldberg SF, Budgeon L, Meehan WJ, Winter CR, Christensen ND, Verderame MF, et al. Analysis of mechanisms underlying BRMS1 suppression of metastasis. Clin Exp Metastasis. 2000; 18:683-693.

21. Polyak K, Weinberg RA. Transitions between epithelial and mesenchymal states: acquisition of malignant and stem cell traits. Nat Rev Cancer. 2009; 9:265-273.
22. Peinado H, Del Carmen Iglesias-de la Cruz M, Olmeda D, Csiszar K, Fong KS, Vega S, Nieto MA, Cano A, Portillo F. A molecular role for lysyl oxidase-like 2 enzyme in snail regulation and tumor progression. EMBO J. 2005; 24:34463458 .

23. Peinado H, Moreno-Bueno G, Hardisson D, Pérez-Gómez E, Santos V, Mendiola M, de Diego JI, Nistal M, Quintanilla M, Portillo F, Cano A. Lysyl oxidase-like 2 as a new poor prognosis marker of squamous cell carcinomas. Cancer Res. 2008; 68:4541-4550.

24. Yang S, Zhang JJ, Huang XY. Orai1 and STIM1 are critical for breast tumor cell migration and metastasis. Cancer Cell. 2009; 15:124-134.

25. Nam JS, Suchar AM, Kang MJ, Stuelten CH, Tang B, Michalowska AM, Fisher LW, Fedarko NS, Jain A, Pinkas J, Lonning S, Wakefield LM. Bone sialoprotein mediates the tumor cell-targeted prometastatic activity of transforming growth factor beta in a mouse model of breast cancer. Cancer Res. 2006; 66:6327-6335.

26. Thomssen C, Pierga JY, Pritchard KI, Biganzoli L, CortesFunes H, Petráková K, Kaufman B, Duenne A, Smith I. First-line bevacizumab-containing therapy for triplenegative breast cancer: analysis of 585 patients treated in the ATHENA study. Oncology. 2012; 82:218-227.

27. Thiery JP, Acloque H, Huang RY, Nieto MA. Epithelialmesenchymal transitions in development and disease. Cell. 2009; 139:871-890.

28. Singh A, Settleman J. EMT, cancer stem cells and drug resistance: an emerging axis of evil in the war on cancer. Oncogene. 2010; 29:4741-4751.

29. Olmeda D, Moreno-Bueno G, Flores JM, Fabra A, Portillo F, Cano A. SNAI1 is required for tumor growth and lymph node metastasis of human breast carcinoma MDA-MB-231 cells. Cancer Res. 2007; 67:11721-11731.

30. Uchikado Y, Natsugoe S, Okumura H, Setoyama T, Matsumoto M, Ishigami S, Aikou T. Slug Expression in the E-cadherin preserved tumors is related to prognosis in patients with esophageal squamous cell carcinoma. Clin Cancer Res. 2005; 11:1174-1180.

31. Bolós V, Peinado H, Pérez-Moreno MA, Fraga MF, Esteller M, Cano A. The transcription factor Slug represses E-cadherin expression and induces epithelial to mesenchymal transitions: a comparison with Snail and E47 repressors. J Cell Sci. 2003; 116:499-511.

32. Aigner K, Dampier B, Descovich L, Mikula M, Sultan A, Schreiber M, Mikulits W, Brabletz T, Strand D, Obrist P, Sommergruber W, Schweifer N, Wernitznig A, et al. The transcription factor ZEB1 (deltaEF1) promotes tumour cell dedifferentiation by repressing master regulators of epithelial polarity. Oncogene. 2007; 26:6979-6988.

33. Spaderna S, Schmalhofer O, Wahlbuhl M, Dimmler A, Bauer K, Sultan A, Hlubek F, Jung A, Strand D, Eger A, 
Kirchner T, Behrens J, Brabletz T. The transcriptional repressor ZEB1 promotes metastasis and loss of cell polarity in cancer. Cancer Res. 2008; 68:537-544.

34. Vandewalle C, Comijn J, De Craene B, Vermassen P, Bruyneel E, Andersen H, Tulchinsky E, Van Roy F, Berx G. SIP1/ZEB2 induces EMT by repressing genes of different epithelial cell-cell junctions. Nucleic Acids Res. 2005; 33:6566-6578.

35. Yang J, Mani SA, Donaher JL, Ramaswamy S, Itzykson RA, Come C, Savagner P, Gitelman I, Richardson A, Weinberg RA. Twist, a master regulator of morphogenesis, plays an essential role in tumor metastasis. Cell. 2004; 117:927-939.

36. Fong SF, Dietzsch E, Fong KS, Hollosi P, Asuncion L, He Q, Parker MI, Csiszar K. Lysyl oxidase-like 2 expression is increased in colon and esophageal tumors and associated with less differentiated colon tumors. Genes Chromosomes Cancer. 2007; 46:644-655.

37. Barry-Hamilton V, Spangler R, Marshall D, McCauley S, Rodriguez HM, Oyasu M, Mikels A, Vaysberg M, Ghermazien H, Wai C, Garcia CA, Velayo AC, Jorgensen B, et al., Allosteric inhibition of lysyl oxidase-like-2 impedes the development of a pathologic microenvironment. Nat Med. 2010; 16:1009-1017.
38. Garber K. BIOMEDICINE. Targeting copper to treat breast cancer. Science. 2015; 349:128-129.

39. Wong CC, Gilkes DM, Zhang H, Chen J, Wei H, Chaturvedi P, Fraley SI, Wong CM, Khoo US, Ng IO, Wirtz D, Semenza GL. Hypoxia-inducible factor 1 is a master regulator of breast cancer metastatic niche formation. Proc Natl Acad Sci U S A. 2011; 108:16369-16374.

40. Liao D, Corle C, Seagroves TN, Johnson RS. Hypoxiainducible factor-1alpha is a key regulator of metastasis in a transgenic model of cancer initiation and progression. Cancer Res. 2007; 67:563-572. 